\title{
Effects of halothane sensitivity on male and female reproductive performance in Pietrain lines
}

\author{
P. SELLIER, V. COUSIN et P. DANDO * \\ INRA, Station de Génétique quantitative et appliquée \\ Centre de Recherches de Jouy-en-Josas \\ F 78350 Jouy-en-Josas \\ * INRA, Domaine de Galle, F 18520 Avord
}

\begin{abstract}
Summary
Records collected in two experimental Pietrain lines were analyzed in order to examine the influence of halothane sensitivity on reproductive performance. Two data sets were utilized. In the purebred Pietrain data set, effects of halothane phenotype ( $\mathrm{HN}=$ halothane-negative, $\mathrm{HP}=$ halothane-positive) of both sires and dams were investigated on 600 mating records and 424 litter records involving $190 \mathrm{HN}$ and $151 \mathrm{HP}$ dams and $41 \mathrm{HN}$ and $35 \mathrm{HP}$ sires. In the Pietrain $\times$ Large White data set, effects of halothane phenotype of a sub-sample of Pietrain sires (26 HN and 25 HP) were estimated using 530 mating records and 422 litter records. The effect of dam halothane phenotype in purebred Pietrain lines was non-significant $(P>.10)$ for all traits. No significant effect of sire halothane phenotype on fertility traits was found in both data sets. The influence of this factor reached $(P<.05)$ or approached $(P<.10)$ significance for a few litter productivity traits, but the results were not consistent between purebred and crossbred litters. Overall, it may be stated that in the two Pietrain lines under study, HP boars and sows did not exhibit poorer reproductive performance than HN ones. This disagrees with earlier studies showing varying reductions in prolificacy of HP sows in other populations. The most likely explanation is that the $\mathrm{H}$ blood group system, closely linked to the halothane locus, plays a greater role, through the adverse effect of the $\mathrm{Ha}$ blood type on litter size.
\end{abstract}

Key words : Pig, Pietrain, halothane sensitivity, reproductive performance.

\section{Introduction}

It is now well-documented that halothane sensitivity affects to a large extent several traits of great economic importance, e.g. postweaning survival rate, killing out percentage, carcass leanness and liability to pale, soft, exudative (PSE) meat condition, as reviewed by WeBB et al. $(1982,1985)$ among others.

As regards reproductive performance, a number of comparisons between halothane-positive and halothane-negative sows have been achieved since the earliest reports by MABRY (1977) and WEBB \& JoRDAN (1978). The populations dealt with in those comparisons were either Pietrain-Hampshire composite lines and British Landrace lines selected for or against positive reaction to halothane exposure (CARDEN et al., 1985 ; SIMPSON et al., 1986) or a variety of national Landrace populations differing in 
incidence of halothane sensitivity, e.g. Belgian Landrace (LAMPo et al., 1985), Dutch Landrace (VAN DER SteEN, 1983), German Landrace (WIlleke et al., 1984 ; GrosseLembeck \& Kalm, 1985 ; Willeke, 1986 ; Schmitten et al., 1987 ; Baulain \& Glodek, 1987), and Swiss Landrace (Schneider et al., 1980 ; Schwörer \& MoREL, 1984). As far as the authors are aware, the influence of halothane sensitivity on sow productivity traits has not been examined so far in Pietrain purebreds.

In addition, evidence is still limited on the extent to which the sire effect on conception rate and litter size is dependent on the halothane status of the boar. Data on the effect of halothane genotype in this respect were reported by SCHNEIDER et al. (1980), LAmpo et al. (1985) and Baulain \& GlodeK (1987), whereas the influence of halothane phenotype on boar semen characteristics was investigated by HILLBRAND \& Glodek (1984), Schlenker et al. (1984) and Pfeiffer et al. (1986).

The objective of this study was to analyze records collected in two Pietrain lines involved in a selection experiment (SELLIER, 1982), in order to assess the effects of halothane sensitivity on some reproductive traits (farrowing rate, number born per litter and preweaning survival rate). Effects of halothane phenotypes of both sires and dams were examined.

\section{Material and methods}

\section{A. Animals}

\section{Pietrain lines}

Starting from a common foundation stock with a medium incidence of halothane sensitivity (around $30 \%$ ), two closed Pietrain lines were contemporaneously subjected to two selection regimes for 7 generations (1973-1981). One line (PA) was selected for increased growth rate and decreased backfat thickness using a performance-test index including daily gain on test $(27-80 \mathrm{~kg})$ and ultrasonic backfat thickness at $80 \mathrm{~kg}$ body weight. The other line (PB) was selected for increased muscular hypertrophy, the selection criterion being a visual score of muscular development given at around $20-25 \mathrm{~kg}$ body weight and derived from that described by Ollivier (1968).

In both lines, 7-9 males and about 35 females were kept for breeding in each generation, and within-sire family selection was conducted. As a general rule, replacement boars and gilts were selected from first-parity litters and breeding sows were discarded after producing two pureline litters. However, a small number of sows from both lines were retained for a longer period of time due to insufficient availability of replacement gilts in certain sire families. More details on the general design of this selection experiment are given by SELLIER (1982).

From generation 2 onwards, all candidate boars and gilts from first-parity litters were tested for halothane sensitivity at $20-25 \mathrm{~kg}$ body weight. Piglets were aged from 12 to 14 weeks at the time of halothane screening, which reduces the risk of misclassification associated with very early ages at testing (e.g. CARden \& WebB, 1984). The duration of the halothane test was defined as five minutes of actual anaesthesia (i.e. from the loss of eye-reflex), and the total length of exposure to halothane (4\% halothane in oxygen flow for inducing anaesthesia, then $2.5 \%$ for maintaining it) was 
6-7 minutes in non-reactor animals. Animals exhibiting rigidity of the hind legs were scored as halothane-positive (HP) whereas those showing no sign of positive reaction after 5 minutes of actual anaesthesia were scored as halothane-negative (HN). When doubtful reactions occurred, animals were usually re-tested on the same day or one week later, and the result of this second test was used to assign halothane phenotype. Numbers of records available in the Pietrain data set, i.e. from both parents of known halothane phenotype (190 $\mathrm{HN}$ and $151 \mathrm{HP}$ dams and $41 \mathrm{HN}$ and $35 \mathrm{HP}$ sires), are reported in table 1 . There were 335 and 265 mating records and 241 and 183 litter records for $\mathrm{HN}$ and $\mathrm{HP}$ females, respectively.

TABLE 1

Distribution of records in the Pietrain data set.

Répartition des données dans le fichier Piétrain.

\begin{tabular}{|c|c|c|c|c|}
\hline $\begin{array}{c}\text { Dam Hal } \\
\text { phenotype } \\
\text { Phénotype Hal } \\
\text { de la mère }\end{array}$ & $\begin{array}{c}\text { Sire Hal } \\
\text { phenotype } \\
\text { Phénotype Hal } \\
\text { du père }\end{array}$ & $\begin{array}{l}\text { Line } \\
\text { Lignée }\end{array}$ & $\begin{array}{c}\text { No. of mating } \\
\text { records } \\
\text { Nombre } \\
\text { de données } \\
\text { d'accouplements }\end{array}$ & $\begin{array}{l}\text { No. of litters } \\
\text { Nombre de portées }\end{array}$ \\
\hline \multirow{2}{*}{ HN } & HN & $\begin{array}{l}\text { PA } \\
\text { PB }\end{array}$ & $\begin{array}{r}189 \\
33\end{array}$ & $\begin{array}{r}137 \\
20\end{array}$ \\
\hline & HP & $\begin{array}{l}\text { PA } \\
\text { PB }\end{array}$ & $\begin{array}{l}60 \\
53\end{array}$ & $\begin{array}{l}44 \\
40\end{array}$ \\
\hline \multirow{2}{*}{$\mathrm{HP}$} & HN & $\begin{array}{l}\mathrm{PA} \\
\mathrm{PB}\end{array}$ & $\begin{array}{l}82 \\
62\end{array}$ & $\begin{array}{l}58 \\
45\end{array}$ \\
\hline & HP & $\begin{array}{l}\mathrm{PA} \\
\mathrm{PB}\end{array}$ & $\begin{array}{r}17 \\
104\end{array}$ & $\begin{array}{l}13 \\
67\end{array}$ \\
\hline
\end{tabular}

(1) Total number of dams : $190 \mathrm{HN}$ (141 PA, 49 PB), $151 \mathrm{HP}$ (66 PA, $85 \mathrm{~PB}$ ).

(2) Total number of sires: $41 \mathrm{HN}(29 \mathrm{PA}, 12 \mathrm{~PB}), 35 \mathrm{HP}$ (11 PA, $24 \mathrm{~PB})$.

\section{Pietrain $\times$ Large White crossing}

In each generation, 4-5 boars used for pure mating in each Pietrain line were randomly mated to second-parity Large White sows (10.4 sows per boar on average). The purpose was to compare the overall merit of crossbred progeny sired by PA or PB boars. The Large White sows were either from the Control or from the Selected line involved in the long-term selection experiment for increased litter size conducted on the same farm (Ollivier \& Bolet, 1981).

A total of 51 Pietrain boars of known halothane phenotype (26 HN and $25 \mathrm{HP}$ ) were used for producing these crossbred litters (tabl. 2). The Pietrain $\times$ Large White data set consists of 280 and 250 mating records and 224 and 198 litter records for HN and HP boars, respectively. 
TABLE 2

Distribution of records in the Pietrain $\times$ Large White data set.

Répartition des données dans le fichier Piétrain $\times$ Large White.

\begin{tabular}{c|c|c|c|c}
\hline $\begin{array}{c}\text { Sire Hal } \\
\text { phenotype } \\
\text { Phénotype Hal } \\
\text { du père }\end{array}$ & $\begin{array}{c}\text { Sire line } \\
\text { Lignée du père }\end{array}$ & $\begin{array}{c}\text { No. of sires } \\
\text { Nombre de pères }\end{array}$ & $\begin{array}{c}\text { No. of sows } \\
\text { mated } \\
\text { Nombre de truies } \\
\text { saillies }\end{array}$ & $\begin{array}{c}\text { No. of litters } \\
\text { Nombre } \\
\text { de portées }\end{array}$ \\
\hline HN & PA & 17 & 181 & 151 \\
PB & 9 & 99 & 73 \\
\hline HP & PA & 8 & 84 & 72 \\
\hline
\end{tabular}

\section{B. Management and traits recorded}

The lines were kept at the INRA experimental farm located at Avord (Cher). Only natural breeding (hand-mating) was practised and teaser boars were used daily to aid in heat detection. Each breeding period generally covered 8-10 weeks for gilts as well as for sows. Females which did not conceive at the first mating were remated to the same boar at each subsequent estrus occurring before the end of the breeding period. Females which had failed to conceive during the 1st-parity breeding period were kept for the 2nd-parity breeding period, unless they had exhibited no estrus at all, had died or had to be culled for serious problems (e.g. leg weakness, injury or disease). Sows were normally mated at the first post-weaning estrus.

Fertility was assessed using four traits :

- farrowing rate, which is the ratio of the number $F$ of normal farrowings (i.e. with at least one piglet born alive) over the number $\mathbf{M}$ of females mated at least once ;

- conception rate for the entire breeding period, which is defined as $\mathrm{C} / \mathrm{M}, \mathrm{C}$ being the number of pregnant females. In addition to $\mathrm{F}, \mathrm{C}$ includes late abortions, abnormal farrowings (e.g. all piglets stillborn) and pregnancies detected in case of death or emergency slaughtering ;

- conception rate for first service ;

- number of services required for each conception.

Breeding females were tethered in stalls during pregnancy and received $2.5-2.7 \mathrm{~kg}$ of feed per day. They were moved into farrowing facilities at least 3 days before they were due to farrow. Farrowings took place in individual pens. Induction of parturition by intramuscular injection of an analogue of prostaglandin $F_{2 \alpha}$ (cloprostenol) was occasionally carried out in the last years of the experiment (SEllier et al., 1988). Numbers of fully formed piglets at farrowing (born alive and stillborn) were recorded. Piglets received iron injection at 3 or 4 days of age. Creep died was made available to piglets at about 10 days of age and male piglets were castrated, except in replacement litters, at about 3 weeks of age. Piglets were weaned during their 6th week of life, i.e. on average at 38 days of age, and litter sizes at weaning were recorded. All litters 
containing at least one piglet born alive were considered in analyzing litter size at birth. All litters born, including those containing no surviving piglet at weaning, were taken into account for analysis of litter size at weaning.

\section{Statistical analysis}

Litter productivity traits and number of services per fertile mating were analyzed by least-squares using the general linear models (GLM) procedure of SAS (SAS Institute, 1985). Data on Pietrain purebreds were fitted to a model including the effects of line (PA or PB), generation number (5 levels : $2, \ldots, 6)$, parity $(1,2,3$ and more), halothane phenotype of the dam $\left(\mathrm{Hal}_{\text {dam }}\right)$, halothane phenotype of the sire $\left(\mathrm{Hal}_{\text {sire }}\right)$, and the interactions of line with $\mathrm{Hal}_{\text {dam }}$, line with $\mathrm{Hal}_{\text {sire }}$, parity with $\mathrm{Hal}_{\text {dam }}$, and $\mathrm{Hal}_{\text {dam }}$ with $\mathrm{Hal}_{\text {sire }}$. For Pietrain $\times$ Large White data, the model included the effects of sire line (PA or PB), sire generation number $(6$ levels : $2, \ldots, 7)$, dam line (2 levels), halothane phenotype of the sire $\left(\mathrm{Hal}_{\text {sire }}\right)$ and the interaction of sire line with $\mathrm{Hal}_{\text {sire }}$. The angular transformation was used for analyzing proportion of stillbirths and survival rate from birth to weaning, also applying the corrections suggested by BARTLETT (1947) for 0 and $100 \%$ proportions. Conception and farrowing rates were treated according to the methods developed by Grizzle et al. (1969) for discrete variables $(0=$ failure and 1 = success), and the same models as above were applied to each of the two data sets. The analysis was based on logits and means were estimated using the maximum likelihood method available in the categorical data modeling (CATMOD) procedure of SAS (SAS Institute, 1985).

\section{Results}

The results of analyses of variance are summarized in table 3 for fertility traits and in table 4 for litter productivity traits.

Generation number was a significant source of variation for most traits, especially for farrowing rate, survival rate from birth to weaning and litter size at weaning in the Pietrain data set. Examination of generation means shows a sharp decline of the two latter traits in the second half of the period of study. The increase in average inbreeding coefficients of the pure Pietrain lines (up to $9.8 \%$ for parents and $10.8 \%$ for offspring in the last generation) has probably contributed to the much higher preweaning mortality rate in late generations. Also, induction of farrowing by means of an analogue of prostaglandin $\mathrm{F}_{2 \alpha}$ was more commonly used in late generations and this may have played a role in the decrease in survival rate of Pietrain piglets.

In the Pietrain data set, parity of dam significantly affected first service conception rate, number of services per fertile mating and litter size at birth. As expected, lower performance levels in these traits were found for first parity as compared to later parities.

The effect of line (PA vs. PB) was generally of low magnitude in the Pietrain data set. The PA line however tended to show an advantage over the PB line in first service conception rate and litter size at birth $(\mathrm{P}<.10)$. This advantage of $\mathrm{PA}$ over $\mathrm{PB}$ in reproductive performance was even larger when both lines were used as sire lines 


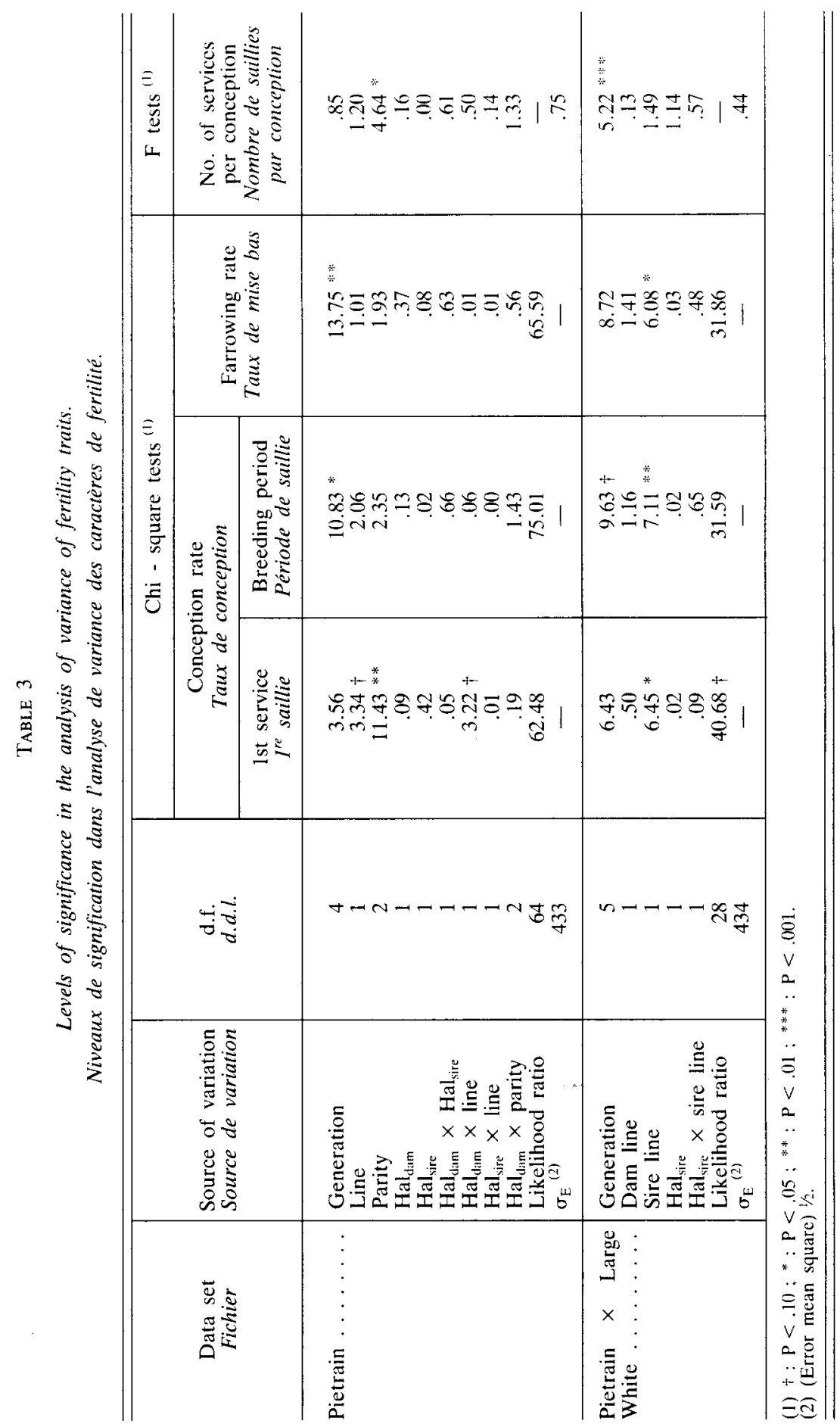




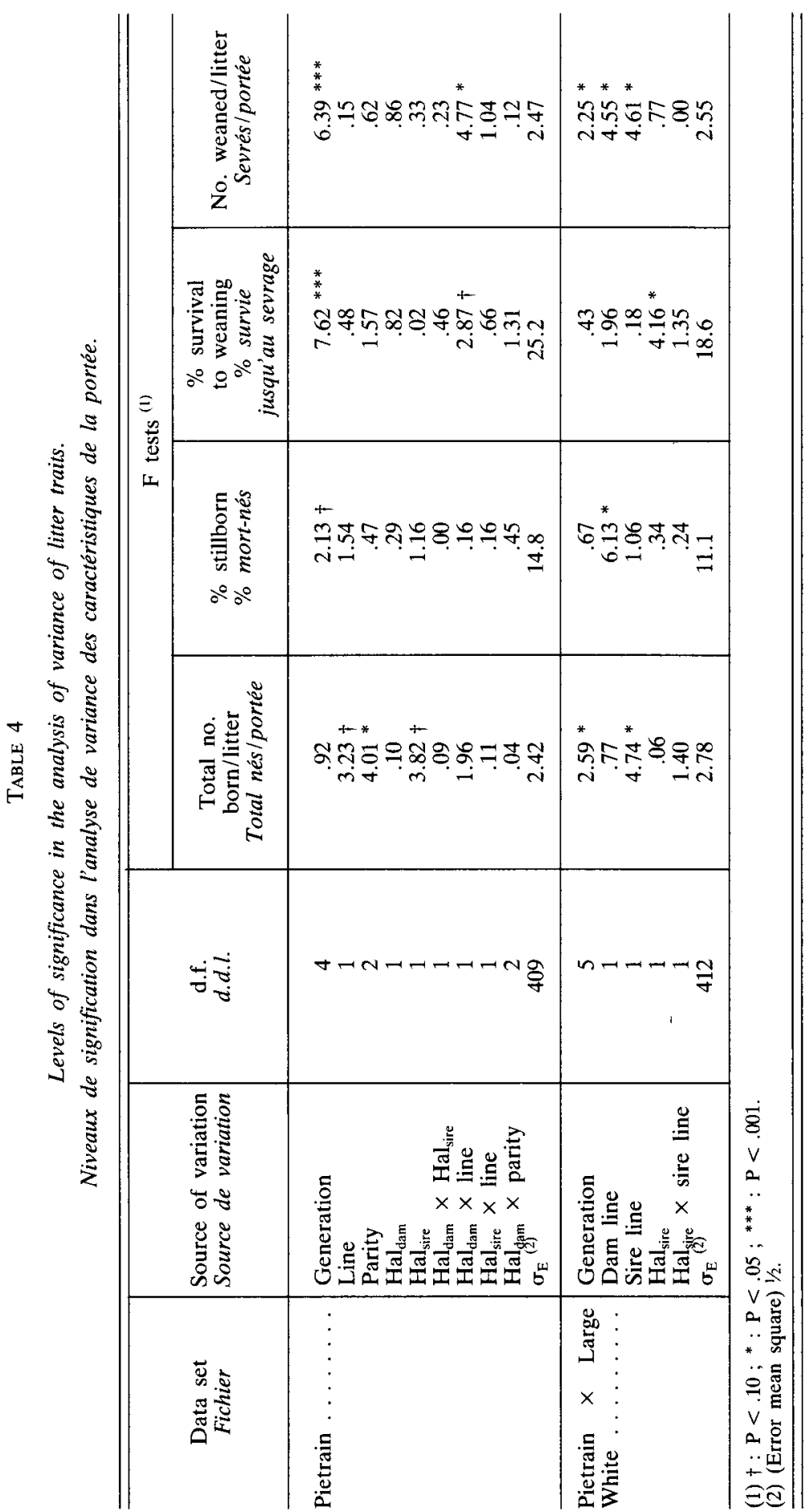




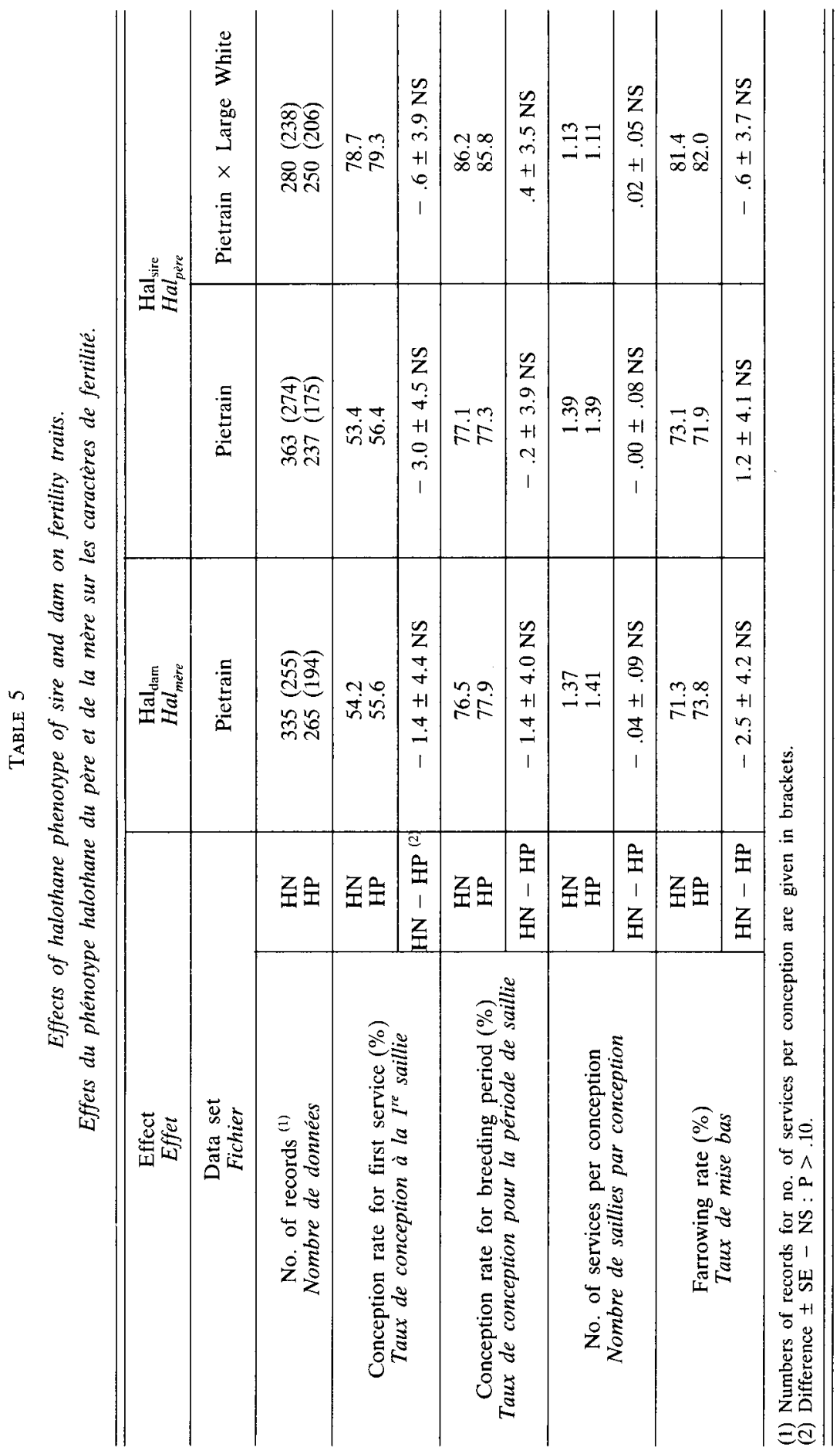




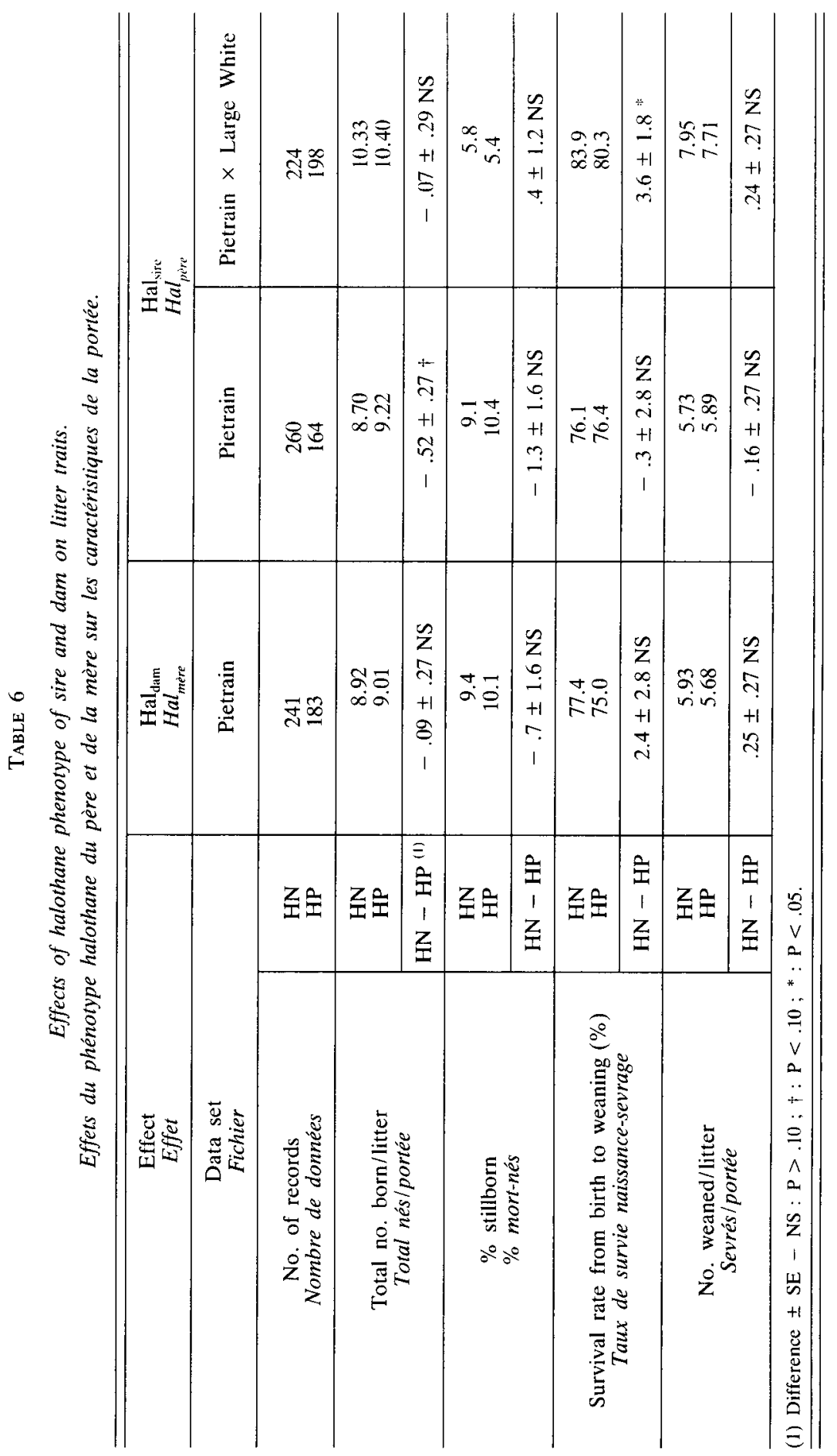


(Pietrain $\times$ Large White data set) : e.g. 89.7 vs. $81.4 \%(\mathrm{P}<.01)$ for conception rate in the entire breeding period, and 10.7 vs. $10.1(\mathrm{P}<.05)$ for number born per litter.

As far as the effects of halothane phenotype of sire and dam are concerned, it should be pointed out that the $\mathrm{Hal}_{\text {dam }} \times \mathrm{Hal}_{\text {sire }}$ interaction was far from statistical significance for all traits. Estimates of relevant means for dam and sire halothane phenotypes are reported in tables 5 (fertility traits) and 6 (litter productivity traits).

The effect of dam halothane phenotype in Pietrain lines was non-significant $(P>.10)$ for all traits. A significant interaction between line and dam halothane phenotype $(\mathrm{P}<.05)$ was however found for litter size at weaning: HN sows, as compared to HP ones, gave significantly better results in this respect in the PA but not in the PB line.

No significant influence of sire halothane phenotype on fertility traits was found. A small number of litter productivity traits were affected by this factor. Survival rate to weaning was lower $(\mathrm{P}<.05)$ in crossbred litters sired by HP Pietrain boars than in those sired by $\mathrm{HN}$ Pietrain boars $(78.1 \mathrm{vs}$. $82.0 \%)$. The effect of sire halothane phenotype on that trait was however near zero in Pietrain purebred litters. On the other hand, there was a tendency $(P<.10)$ towards a higher number of piglets born in purebred litters sired by HP Pietrain boars than in those sired by HN Pietrain boars (9.22 vs. 8.70). However, the effect of sire halothane phenotype on litter size at birth was of much lower magnitude in Pietrain $\times$ Large White litters.

\section{Discussion}

On the whole, this analysis does not provide evidence that halothane phenotype affects the reproductive performance of breeding animals in the two Pietrain lines under study.

\section{A. Male reproductive performance}

Regarding boar reproductive performance, the effect of halothane phenotype achieves or approaches statistical significance in only a small number of cases, but the results are not consistent according to whether the Pietrain boars are used in purebreeding or in crossbreeding with Large White sows. In any case, there is no evidence that HP Pietrain boars have poorer reproductive performance than $\mathrm{HN}$ ones. With regard to the sire effect on number born per litter, the observed trend even favours the HP boars. This is in accordance with the significant advantage of HP over HN boars found in this respect by ScHNEIDER et al. (1980) in the Swiss Landrace breed and by Baulain \& Glodek (1987) in the German Landrace breed. No noticeable difference in number born for litters sired by HP or HN boars from the Belgian Landrace breed was however found by LAMPo et al. (1985). It was reported by SCHLENKER et al. (1984) that ejaculates from HP boars have smaller volumes and contain a lower number of sperms than those from HN boars. An opposite conclusion was reached by HillbRand \& GLODEK (1984) as regards the total number of sperms per ejaculate. Better semen quality in HN as compared to HP boars was found by PFEIFFER et al. (1986). 


\section{B. Female reproductive performance}

The halothane phenotype of the dam did not affect to a significant extent fertility traits in the present study, but conception and farrowing rates appear to be slightly higher (by about 2 percentage points) in HP dams. In the Dutch Landrace breed, conception rate for $\mathrm{HN}$ and $\mathrm{HP}$ gilts bred by $\mathrm{AI}$ was 70 and $75 \%$, respectively (VAN DER STEEN, 1983), whereas conception rate for $\mathrm{HN} \times \mathrm{HN}$ and $\mathrm{HP} \times \mathrm{HP}$ matings was 77 and $79 \%$, respectively, in British Landrace lines (Simpson et al., 1986). No effect of the sow halothane genotype on farrowing interval was found in the German Landrace breed (BAULAIN \& GLODEK, 1987). These results altogether suggest that HP sows are similar or even a little superior to $\mathrm{HN}$ sows from the same breed in the ability to become pregnant. However, Baulain \& Glodek (1987) reported that age at first farrowing is significantly higher (by 2 weeks, on average) in HP gilts.

No significant effect of the halothane phenotype of Pietrain dams on litter size at birth or at weaning was found in the present study. Several studies dealing with other breeds have been previously published on this aspect. Results generally favour $\mathrm{HN}$ sows, but with a large variation between studies. A significant advantage of $\mathrm{HN}$ over HP breeding females for number born per litter was reported in the Swiss Landrace breed $(+.55$ born alive) by SchNeIDER et al. $(1980)$, in Dutch Landrace gilts $(+1.3$ born) by VAN DER STEEN (1983), and in Pietrain-Hampshire composite lines $(+1.2 \pm .4$ in litter size at birth) by CARDEN et al. (1985). In a field study on the Belgian Landrace breed, LAMPO et al. (1985) found no difference in litter size at birth between HN and HP gilts, whereas HN sows were more prolific (by about .5 piglets) in the second and later parities. Several studies on the German Landrace breed (WILleKe et al., 1984 ; Grosse-Lembeck \& Kalm, 1985 ; Willeke, 1986 ; Schmitten et al., 1987 ; Baulain \& GLODEK, 1987) all point to a slightly better prolificacy (up to +.40 piglets born per litter) for HN sows as compared to HP sows, although the difference does not reach statistical significance in any of these comparisons. In addition, a better longevity of the HN sows, assessed by the lifetime number of litters, was shown by WILLEKE (1986). No difference in number born alive per litter between $\mathrm{HN} \times \mathrm{HN}$ and $\mathrm{HP} \times \mathrm{HP}$ matings carried out in two British Landrace lines was found by Simpson et al. (1986), and a non-significant trend in favour of $\mathrm{HN} \times \mathrm{HN}$ litters was observed in litter size at 42 days. The results of the present study are in good agreement with those of the latter study. However, in the study by SIMPSON et al. (1986), there was strong evidence that halothane sensitivity of dam and (or) offspring exerts a negative influence on offspring growth from the 30th day of pregnancy until weaning, whereas in our Pietrain lines the effects of halothane phenotype of sire and dam on individual weaning weight were rather limited, and also dependent on dam parity (Cousin, 1985).

\section{Possible role of the $H$ blood group system}

The large variation among the published estimates of the difference in prolificacy between $\mathrm{HN}$ and HP females from the same population causes concern. A number of factors may account for those discrepancies, including :

1) sampling variation ;

2) environmental differences (e.g. age of dam and type of mating) ;

3) incomplete reliability of the halothane test ; 
4) varying genotypic frequencies (normal homozygotes vs. heterozygotes) within the halothane-negative group ; and

5) differences in genetic background, i.e. at loci other than the halothane locus.

As regards the variation of genotypic frequencies among $\mathrm{HN}$ animals, no attempt was made in the present study to predict individual halothane genotypes of breeding boars and sows. However, considering the average incidence of halothane sensitivity in the PA and PB lines (about 35 and $65 \%$, respectively), it may be anticipated that most $\mathrm{HN}$ individuals were heterozygous at the halothane locus, especially in the PB line. The low proportion of normal homozygotes among $\mathrm{HN}$ individuals (probably less than $20 \%$ on average over the two lines) could partly explain the lack of significant differences between halothane phenotypes in the present study, as compared to other studies.

The role possibly played by differences in genetic background between halothane phenotypes (or genotypes) deserves special attention. A number of blood markers have been assigned to the chromosomal region encompassing the halothane locus ( $\mathrm{Hal}$ ), as reviewed by ARCHIBALD \& IMLAH (1985), and the $\mathrm{H}$ blood group system is known to be closely linked to the Hal locus. Earlier American studies (JENSEN et al., 1968 ; RASMUSEN \& HAGEN, 1973 ; RASMUSEN, 1976) have shown that H blood types affect reproductive traits in breeds which are free (or almost free) from the halothane sensitivity gene (e.g. Duroc). They all indicate that the Ha blood type exerts a negative effect on litter size. There are reasons for hypothesizing that, in some of the abovecited comparisons, the significant reduction in litter size could result solely from the $\mathbf{H}$ rather than the Hal locus. For instance, in the study by CARDEN et al. (1985), the comparison between halothane phenotypes was, in fact, a comparison between two Pietrain-Hampshire composite lines selected for or against halothane sensitivity, and the allelic frequencies in " $\mathrm{HP}$ " and " $\mathrm{HN}$ " lines differed not only at the Hal locus (due to selection) but also at the $H$ locus (through a «hitch-hiking effect»). A large divergence in the frequencies of certain $\mathrm{H}$ blood group factors was indeed found between these lines by IMLAH (1982), with the factor Ha being much more frequent in the "HP" than in the "HN" line. So, the markedly reduced litter size in HP sows might as well be attributed to the $\mathrm{H}$ blood group locus as to the Hal locus.

As for the advantage of HN over HP sows in prolificacy observed in several studies dealing with Landrace populations, it might also arise through an effect of the $\mathrm{H}$ blood group locus, due to the non-random combinations of $\mathrm{Hal}$ and $\mathrm{H}$ genes in those populations : preferential associations of the halothane sensitivity gene with the $H^{a}$ gene have indeed be reported in a number of national populations of European Landrace (e.g. ANDrESEN, 1980 ; Vögeli \& Schwörer, 1982 ; EiffErT et al., 1986).

Although the time trends in gene frequencies at the $\mathbf{H}$ locus were not systematically followed in the Pietrain lines of the present study, there are some indications that the $H^{a}$ allele was at a very high frequency in both lines. In the middle of the selection experiment (generations 3 and 4), blood typing for the $H$ system was carried out in around fifty litters from both lines for another purpose (see Guerin et al., 1983). All pigs were found to be positive to the $\mathrm{Ha}$ reagent and negative to both $\mathrm{Hb}$ and $\mathrm{Hc}$ reagents. It therefore appears that animals from those particular Pietrain lines were predominantly $H^{a} / H^{a}$, whatever their halothane phenotype. That HN and HP sows of the present study have similar $H$ blood types, contrary to most of other comparable studies, may be proposed as an explanation for their close similarity in prolificacy. 


\section{Conclusion}

The results of this study support the view that the halothane locus per se might have no actual influence on sow prolificacy and other reproductive traits. The lower prolificacy of halothane-positive sows (from - .1 to -1.3 piglets born) in other studies might be explained by the effect of the Ha blood type. Anyway, it must be emphasised that inferences about the effect of halothane sensitivity on reproductive performance cannot be extented from one population to another. Designs which can separate the respective effects of the halothane sensitivity locus and the $H$ blood group system would merit further investigation, in an attempt to increase our knowledge of the way in which the chromosomal region embracing $\mathrm{Hal}, \mathrm{H}$ and other loci influences reproductive traits.

Reçu en avril 1987.

Accepté en août 1987.

\section{Achnowledgements}

The contributions of Geneviève LE Henaff, Michèle JosePh, Françoise Bouchain and H. JOUET are gratefully acknowledged.

\section{Résumé}

\section{Effets de la sensibilité à l'halothane sur les performances de reproduction des verrats et des truies dans des lignées Piétrain}

Les données recueillies dans deux lignées Piétrain ont été analysées afin d'évaluer l'influence de la sensibilité à l'halothane sur certains caractères de reproduction. Deux fichiers de données ont été utilisés. Dans le fichier «Piétrain pur ", les effets du phénotype halothane du père et de la mère $(\mathrm{HN}=$ halothane-négatif, $\mathrm{HP}=$ halothane-positif) ont été estimés à partir des résultats de 600 accouplements et 424 portées, provenant de 341 truies $(190 \mathrm{HN}, 151 \mathrm{HP})$ et 76 verrats (41 HN, $35 \mathrm{HP}$ ). Dans le fichier "Piétrain $\times$ Large White ", les effets du phénotype halothane d'un sous-échantillon des pères Piétrain $(26 \mathrm{HN}, 25 \mathrm{HP})$ ont été estimés à partir des résultats de 530 accouplements et 422 portées. L'effet du phénotype halothane de la mère dans les lignées pures Piétrain s'est révélé non-significatif $(\mathrm{P}>0,10)$ pour tous les caractères. Aucun effet significatif du phénotype halothane du père sur les caractères de fertilité n'a été observé dans les deux fichiers. L'effet de ce facteur a atteint $(\mathrm{P}<0,05)$ ou approché $(\mathrm{P}<0,10)$ la signification pour quelques caractéristiques de la portée, mais les résultats ne concordent pas en race pure et en croisement. $\mathrm{Au}$ total, on peut conclure que dans les lignées Piétrain étudiées, les verrats et les truies sensibles à l'halothane n'ont pas été inférieurs aux verrats et aux truies non-sensibles en termes de performances de reproduction. Ce résultat n'est pas en accord avec ceux d'études antérieures qui font état d'une réduction plus ou moins marquée de la prolificité des truies sensibles dans d'autres populations. L'explication la plus plausible est que le système $\mathrm{H}$ de groupe sanguin, étroitement lié au locus de la sensibilité à l'halothane, joue un rôle plus important, par le biais de l'effet défavorable du facteur Ha de groupe sanguin sur la taille de portée.

Mots clés : Porc, Piétrain, sensibilité à l'halothane, performances de reproduction. 


\section{References}

ANDRESEN E., 1980. Association between susceptibility to the malignant hyperthermia syndrome (MHS) and $\mathrm{H}$ blood types in Danish Landrace pigs explained by linkage disequilibrium. Livest. Prod. Sci., 7, 155-162.

Archibald A.L., Imlah P., 1985. The halothane sensitivity locus and its linkage relationships. Anim. Blood Grps Biochem. Genet., 16, 253-263.

BartLetT M.S., 1947. The use of transformations. Biometrics, 3, 39-52.

Baulain U., Glodek P., 1987. Beziehungen zwischen Halothanreaktion und Zuchtleistung bei Sauen verschiedener Populationen. Züchtungskunde, 59, 122-134.

Carden A.E., Webs A.J., 1984. The effect of age on halothane susceptibility in pigs. Anim. Prod., 38, 469-475.

Carden A.E., Hill W.G., WebB A.J., 1985. The effects of halothane susceptibility on some economically important traits in pigs. 1. Litter productivity. Anim. Prod. 40, 351-358.

Cousin V., 1985. Effets d'une sélection en faveur du développement musculaire et effets de la sensibilité à l'halothane sur les performances de reproduction en race Piétrain. Mémoire de fin d'études à l'Institut Supérieur d'Agriculture de Lille, INRA, Station de Génétique quantitative et appliquée, $72 \mathrm{p}$.

Eiffert L., Meyer J.N., Glodek P., Kallweit E., Smidt D., 1986. Untersuchungen zum Halothantest in verschiedenen Deutschen Schweinepopulationen. 3. Mitteilung: Beziehungen zwischen der Halothanreaktion und dem Genotyp an bekannten Markerloci. Züchtungskunde, 58, 54-65.

Grizzle J.E., Starmer C.F., Косн G.G., 1969. Analysis of categorical data by linear models. Biometrics, 25, 489-504.

Grosse-Lembeck K., Kalm E., 1985. Eignung verschiedener Stressempfindlichkeitstests zur Entwicklung von Mutterlinien, dargestellt an der Deutschen Landrasse in Schleswig-Holstein. Züchtungskunde, 57, 99-112.

Guerin G., Ollivier L., Sellier P., 1983. Etude du groupe de liaison Hal, Phi et Pgd chez le Porc : disposition relative des trois locus et estimation des taux de recombinaison. Génét. Sél. Evol., 15, 55-63.

Hillbrand F.W., Glodek P., 1984. Halothane sensitivity and semen quality of boars in 3 lines of pigs. $35^{\text {th }}$ Annual Meeting of the E.A.A.P., The Hague, Summaries, vol. 2, P. 5.11 (Abstr.).

IмLAH P., 1982. Linkage studies between the halothane (Hal), phosphohexose isomerase ( $\mathrm{Phi}$ ) and the $\mathrm{S}(\mathrm{A}-\mathrm{O})$ and $\mathrm{H}$ red blood cell loci of Pietrain/Hampshire and Landrace pigs. Anim. Blood Grps Biochem. Genet., 13, 245-262.

Jensen E.L., Smith C., Baker L.N., Cox D.F., 1968. Quantitative studies on blood group and serum protein systems in pigs. II. Effects on production and reproduction. J. Anim. Sci., 27, 856-862.

Lampo Ph., Nauwynck W., Bouquet Y., Van Zeveren A., 1985. Effect of stress susceptibility on some reproductive traits in Belgian Landrace pigs. Livest. Prod. Sci., 13, 279-287.

MABRY J.W., 1977. Porcine stress syndrome: Inheritance, prediction and performance characteristics. Ph. D. Thesis, Iowa State University, Ames, Iowa, U.S.A., 102 p.

Ollivier L., 1968. Etude du déterminisme héréditaire de l'hypertrophie musculaire du porc de Piétrain. Ann. Zootech., 17, 393-407.

Ollivier L., Bolet G., 1981. La sélection sur la prolificité chez le porc: résultats d'une expérience de sélection sur dix générations. In : $13^{\text {es }}$ Journées de la Recherche Porcine en France, 261-267, INRA, Institut Technique du Porc, Paris.

Pfeiffer H., Lengerken G.v., Schwalbe M., Horn P., Kovach G., 1986. Relationships between the stress susceptibility and the fertility of pigs. $37^{\text {th }}$ Annual Meeting of the E.A.A.P., Budapest, Summaries, vol. 1, GP 3.20, 140-141 (Abstr.).

RASMUSEN B.A., 1976. Relationships between blood types and reproductive performance in pigs. Proc. $4^{\text {th }}$ Congr. Intern. Pig Veter. Soc., June 22-24, 1976, Ames, Iowa, U6.

Rasmusen B.A., Hagen K.L., 1973. The H blood-group system and reproduction in pigs. $J$. Anim. Sci., 37, 568-573. 
SAS Institute Inc., 1985. SAS ${ }^{\circledR}$ User’s Guide : Statistics Version 5 Edition. SAS Institute Inc., Cary, North Carolina, U.S.A., 956 p.

Schlenker G., Jugert L., Mudra K., Pohle M., Heinze C., 1984. Spermaqualität von Ebern unterschieldlicher Halothanempfindlichkeit. Mh. Vet.-Med., 39, 760-763.

Schmitten F., Festerling A., Jungst H., Schepers K.H., 1987. Results of crossbreeding experiments using meat type boars and stress resistant sows. In : Tarrant P.V., Eikelenboom G., Monin G. (Eds), Evaluation and control of meat quality, 387-391. Martinus Nijhoff Publishers, Dordrecht, The Netherlands.

Schneider A., Schwörer D., Blum J., 1980. Beziehung des Halothan-Genotyps zu den Produktions- und Reproduktionsmerkmalen der Schweizerischen Landrasse. $31^{s t}$ Annual Meeting of the E.A.A.P., Munich, GP 3.9 .

SChwÖRER D., Morel P., 1984. Beziehung zwischen der Halothanreaktion und der Fruchtbarkeit beim Schwein. Schweiz. Landwirtsch. Monatsh., 62, 260-267.

Sellier P., 1982. Preliminary results of a selection experiment for muscle hypertrophy in the Pietrain breed. In : KING J.W.B., MENISSIER F. (Eds), Muscle hypertrophy of genetic origin and its use to improve beef production, 537-547. Martinus Nijhoff Publishers, The Hague.

Sellier P., Dando E., Dando P., 1988. Relationships of incidence of splayleg syndrome with gestation length in natural and artificially induced farrowings from Large White and Pietrain sows (in preparation).

Simpson S.P., WebB A.J., Wilmut I., 1986. Performance of British Landrace pigs selected for high and low incidence of halothane sensitivity. 1. Reproduction. Anim. Prod., 43, 485-492.

VAN DER STEEN H.A.M., 1983. Maternal and genetic influences on production and reproduction traits in pigs. Doctoral thesis, Agricultural University, Wageningen, The Netherlands, $112 \mathrm{p}$.

VögELI P., SchwöRER D., 1982. Kopplungsungleichgewitch zwischen dem Malignen Hyperthermie Syndrom (MHD, Halothanempfindlichkeit) und den Phänotypen des H-Bluttgruppensystems und des PHI-Enzymsystems beim Schweizerischen Veredelten Landschwein. Züchtungskunde, 54, 124-130.

WeBb A.J., JoRdan C.H.C., 1978. Halothane sensitivity as a field test for stress-susceptibility in the pig. Anim. Prod., 26, 157-168.

Webr A.J., Carden A.E., Smith C., Imlah P., 1982. Porcine stress syndrome in pig breeding. In : $2^{\text {nd }}$ World Congress on Genetics applied to Livestock Production, Madrid, Vol. 5, 588-608. Editorial Garsi, Madrid.

Werb A.J., Southwood O.I., Simpson S.P., Carden A.E., 1985. Genetics of porcine stress syndrome. In : LudvigSen J.B. (Ed.), Stress susceptibility and meat quality in pigs, 9-30, E.A.A.P. Publication $\mathbf{n}^{\circ} 33$.

WILLEKE H., 1986. A note on the effect of the halothane-type of sows on lifetime prolificacy and litter parity at culling. Livest. Prod. Sci., 14, 205-210.

Willeke H., Amler K., Fischer K., 1984. Der Einfluss des Halothanstatus der Sau auf deren Wurfgrösse. Züchtungskunde, 56, 20-26. 